\title{
Accumulation of starch in Zn-deficient rice
}

\author{
Motofumi Suzuki ${ }^{1}$, Khurram Bashir ${ }^{1}$, Haruhiko Inoue ${ }^{1}$, Michiko Takahashi ${ }^{1}$, Hiromi Nakanishi ${ }^{1}$ and \\ Naoko K Nishizawa ${ }^{1,2^{*}}$
}

\begin{abstract}
Zinc ( $\mathrm{Zn})$ is an essential micronutrient for living organisms, and understanding the molecular mechanisms of Zn deficiency may help to develop strategies to mitigate this problem. Microarray analysis of $\mathrm{Zn}$ deficient rice revealed the up-regulation of several genes involved in $\mathrm{Zn}$ transport. Moreover many genes involved in starch synthesis/ transport were up-regulated by Zn deficiency in rice roots and shoots. Furthermore, starch granules were detected mainly in the cortical cells of these tissues. The gene encoding inactive RNase was much more highly transcribed than those encoding active RNases. Although the level of RNA degradation in a crude extract of Zn-deficient shoots was higher than that of Zn-sufficient shoots, addition of $\mathrm{Zn}$ significantly reduced the level of degradation. These results indicate that RNA degradation could be regulated by the amount of $\mathrm{Zn}$ in the cell, and that the tolerance of rice plants to low levels of $\mathrm{Zn}$ is promoted by the accumulation of starch and inactive RNase.
\end{abstract}

Keywords: Microarray, Rice, RNase, Starch accumulation, Zinc, Zinc deficiency

\section{Background}

Zinc (Zn) is an essential micronutrient for almost all organisms, and its deficiency represents a serious nutritional problem in humans and plants. $\mathrm{Zn}$ is a non redox active element and serves as a cofactor for large number of enzymes involved in DNA transcription, protein, nucleic acid, carbohydrate, and lipid metabolism (Ishimaru et al. 2011; Broadley et al. 2007; Marschner 1995). For example, DNA and RNA polymerases require $\mathrm{Zn}$ as a cofactor, and $\mathrm{Zn}$ is also essential for cell division. Indeed, $\mathrm{Zn}$ concentration in plant meristems is much higher than in other tissues (Kitagishi \& Obata 1986). Zn also plays a role in the structural stability of certain proteins, such as those containing $\mathrm{Zn}$-finger domains, a dominant feature of many transcription factors. Genomic research in Arabidopsis revealed that roughly $22 \%$ of transcription factors contain a $\mathrm{Zn}$-finger domain (Riechmann et al. 2000); therefore, $\mathrm{Zn}$ may be important in regulating gene expression.

Many regions of the world, particularly those with calcareous soils, lack sufficient $\mathrm{Zn}$, resulting in poor plant growth. Therefore, the mechanism for tolerance to $\mathrm{Zn}$ deficiency should be elucidated to mitigate $\mathrm{Zn}$ deficiency. Several mechanisms have been investigated to clarify the

\footnotetext{
* Correspondence: annaoko@mail.ecc.u-tokyo.ac.jp

${ }^{1}$ Graduate School of Agricultural and Life Sciences, The University of Tokyo, 1-1-1 Yayoi, Bunkyo-ku, Tokyo 113-8657, Japan

${ }^{2}$ Research Institute for Bioresources and Biotechnology, Ishikawa Prefectural University, 1-308 Suematsu, Nonoichi-shi, Ishikawa921-8836, Japan
}

physiological basis of differential Zn efficiency among wheat genotypes. For example, cultivars tolerant to $\mathrm{Zn}$ deficiency secrete higher amounts of mugineic acid family phytosiderophores (MAs) than intolerant cultivars (Cakmak et al. 1994; Walter et al. 1994; Zhang et al. 1989; Suzuki et al. 2006; Cakmak et al. 1996). MAs are synthesized from Lmethionine (Mori \& Nishizawa 1987; Shojima et al. 1990; Ma et al. 1995; Ma et al. 1999). Nicotianamine (NA) synthase (NAS) transforms three molecules of S-adenosyl-Lmethionine to one molecule of NA, and NA aminotransferase (NAAT) catalyzes the amino transfer of NA. The keto form is subsequently reduced to 2'-deoxymugineic acid (DMA) by DMA synthase (DMAS) (Bashir et al. 2006; Bashir \& Nishizawa 2006; Bashir et al. 2010). Zn-DMA, is suggested to be preferred over $\mathrm{Zn}^{2+}$ for uptake in barley roots (Suzuki et al. 2006), while rice roots absorb less $\mathrm{Zn}$ DMA compared to $\mathrm{Zn}^{2+}$ (Suzuki et al. 2008). Similarly the secretion of MAs increases in Zn deficient barley, while it decreases in rice (Suzuki et al. 2006; Suzuki et al. 2008). Despite this, Zn-DMA is suggested to be the preferred form for the long distance transport in rice (Suzuki et al. 2008). Difference in DMA secretion is suggested to increase tolerance in rice (Widodo et al. 2010). Moreover, a modelling study also proposed a strong correlation between DMA secretion and rooting density, and suggested a role of DMA for $\mathrm{Zn}$ absorption in rice (Ptashnyk et al. 2011). The identification of Zn-NA complexes in rice phloem sap also 
suggests that NA performs a significant role in $\mathrm{Zn}$ transport (Nishiyama et al. 2012). Zn uptake by roots, and translocation within the plant, are associated with $\mathrm{Zn}$ efficiency (Rengel \& Graham 1996), while the availability of $\mathrm{Zn}$ at the cellular level is also suggested to be related to $\mathrm{Zn}$ efficiency (Cakmak et al. 1997). Moreover the expression level or activity of enzymes requiring $\mathrm{Zn}$ is shown to be different between Zn-efficient and Zn-inefficient cultivars (Hacisalihoglu et al. 2003). Partitioning of carbohydrates also shows correlation with tolerance to Zn-deficiency stress (Pearson \& Rengel 1997). Rice cultivars differing in $\mathrm{Zn}$ efficiency have been used for physiological and genetic analyses of tolerance to Zn deficiency (Gao et al. 2005; Hajiboland et al. 2005; Hoffland et al. 2006; Wissuwa et al. 2006). Among graminaceous plants, rice is highly sensitive to $\mathrm{Zn}$-deficient stress; thus, we investigated the physiological change and gene expression pattern in rice during $\mathrm{Zn}$ deficiency. Profiling of the genes involved in Zn-deficient stress is critical to elucidate the mechanisms of tolerance to or damage by $\mathrm{Zn}$ deficiency. We performed a microarray analysis with $\mathrm{Zn}$-deficient and $\mathrm{Zn}$-sufficient rice to identify genes whose expression increases in response to $\mathrm{Zn}$ deficiency. Based on our combined expression and phenotypic analyses, we demonstrated that besides up-regulation of genes involved in $\mathrm{Zn}$ uptake and transport, $\mathrm{Zn}$ deficiency enhances starch accumulation both in roots and shoots, and that $\mathrm{Zn}$ deficiency induces the expression of a gene encoding putative inactive RNase, which may function as vegetative storage protein. Further, the level of RNA degradation was increased by $\mathrm{Zn}$ deficiency.

\section{Results}

\section{Up-regulation of genes involved in $\mathrm{Zn}$ transport}

Microarray analysis revealed that the genes involved in $\mathrm{Zn}$ uptake and transport were up-regulated, both in roots and shoots of $\mathrm{Zn}$ deficient rice. The expression of OsNAS1 particularly increased in rice shoots (Table 1). OsNAS1 is reported to be up-regulated by iron deficiency in root and shoot tissue (Inoue et al. 2003; Bashir et al. 2011; Ishimaru et al. 2009). Moreover, the expression of OsNAS3 was also upregulated in root and shoot tissue. The expression of OsNAS3 is not regulated by Fe deficiency and is reported to be up-regulated by $\mathrm{Zn}$ deficiency (Suzuki et al. 2008). As NA was not detected in $\mathrm{Zn}$ deficient rice shoot, the NA catalyzed by OsNAS3 may be transformed to DMA (Suzuki et al. 2008). The up-regulation of OsNAAT1 supports this hypothesis. Besides this the expression of $\mathrm{Zn}$ transporters, OsZIP4, OsZIP5 and OsZIP8 increased significantly in $\mathrm{Zn}$ deficient roots and shoots, while the expression of OsZIP7 increased in shoot tissue (Table 1). OsZIP4 and OsZIP5 are plasma membrane $\mathrm{Zn}$ transporters induced by $\mathrm{Zn}$ deficiency (Lee et al. 2010; Yang et al. 2009; Ishimaru et al. 2005). Moreover, the expression of OsHMA1 was
Table 1 Microarray analysis of genes involved in $\mathrm{Zn}$ transport

\begin{tabular}{llll}
\hline Accession & Gene & \multicolumn{2}{l}{ Ratio $(-Z n /+Z n)$} \\
\cline { 3 - 4 } No. & & $0.9 \pm 0.4$ & Root \\
\hline AK112069 & OsNAS1 & $0.9 \pm 0.4$ & $1.2 \pm 0.1$ \\
AK112011 & OsNAS2 & $4.1 \pm 0.4$ & $2.7 \pm 0.4$ \\
AK070656 & OsNAS3 & $10.6 \pm 1.0$ & $6.0 \pm 0.6$ \\
AK108576 & OsNAAT1 & $1.0 \pm 0.1$ & $1.0 \pm 0.1$ \\
AK107681 & OsIRT1 & $1.0 \pm 0.1$ & $1.2 \pm 0.0$ \\
AY302058 & OsZIP1 & $1.1 \pm 0.2$ & $1.2 \pm 0.2$ \\
AK121551 & OsZIP2 & $0.7 \pm 0.3$ & $1.1 \pm 0.2$ \\
AK069804 & OsZIP3 & $11.2 \pm 0.1$ & $55.2 \pm 4.1$ \\
AK105258 & OsZIP4 & $3.8 \pm 0.3$ & $8.1 \pm 0.3$ \\
AK070864 & OsZIP5 & $1.1 \pm 0.1$ & $1.2 \pm 0.1$ \\
AK103730 & OsZIP6 & $1.8 \pm 0.1$ & $2.3 \pm 0.0$ \\
AK071272 & OsZIP7 & $6.0 \pm 0.3$ & $8.9 \pm 1.3$ \\
AY327038 & OsZIP8 & $1.5 \pm 0.6$ & $1.0 \pm 0.1$ \\
Os05g0472400 & OsZIP9 & $1.0 \pm 0.1$ & $1.0 \pm 0.0$ \\
Os06g0566300 & OsZIP10 & $2.3 \pm 0.0$ & $5.8 \pm 0.1$ \\
Os05g0198400 & Zinc transporter & $1.7 \pm 0.5$ & $7.4 \pm 2.0$ \\
Os06g0690700 & OsHMA1 & & \\
\hline
\end{tabular}

also induced by Zn deficiency in shoot tissue. OsHMA1 is supposed to be involved in $\mathrm{Zn}$ transport (Williams \& Mills 2005).

\section{Starch accumulation in $\mathrm{Zn}$-deficient roots and shoots}

As shown in Table 2, genes encoding starch synthase, ADP-glucose pyrophosphorylase (AGPase) large subunit, AGPase small subunit, $\alpha-1,4$-glucan branching enzyme, and phosphoglucomutase, which are thought to be involved in starch metabolism, were up-regulated by $\mathrm{Zn}$ deficiency. Sucrose synthase, which reversibly converts sucrose to ADP-glucose, was up-regulated in $\mathrm{Zn}$-deficient shoots and slightly up-regulated in roots, while $\alpha-1,4$-glucan phosphorylase, which catalyzes the phospholysis of a linear glucan chain to reversibly yield glucose 1-phosphate (Smith et al. 2003), was also up-regulated. Although multiple pathways may exist for starch synthesis (Baroja-Fernández et al. 2004), the above enzymes may be sufficient for starch synthesis. Moreover, several genes involved in sugar transporter were up-regulated especially in shoots. The expression of these genes increased more significantly, when plants were subjected to $\mathrm{Zn}$ deficiency and analysed by $22 \mathrm{~K}$ microarray analysis (Additional file 1: Table S1).

The starch content was higher in both roots and shoots grown under $\mathrm{Zn}$-deficient conditions (Figure 1a), corresponding to the gene expression pattern revealed by our microarray analysis. Iodine-starch reaction staining revealed starch accumulation in $\mathrm{Zn}$-deficient roots, but not in control roots or Fe-deficient roots (Figure 1b-d). 
Table 2 Microarray analysis of genes involved in carbohydrate metabolism and transport in rice

\begin{tabular}{llll}
\hline Accession & Putative gene identification & \multicolumn{2}{l}{ Ratio (-Zn/+Zn) } \\
\cline { 4 - 4 } & & Root & Shoot \\
\hline Starch metabolism and transport & $3.5 \pm 0.4$ & $2.5 \pm 0.8$ \\
AK102058 & Starch synthase & $2.4 \pm 0.2$ & $2.7 \pm 0.3$ \\
AK100910 & AGPase large subunit & $2.0 \pm 0.4$ & $2.2 \pm 0.2$ \\
AK073146 & AGPase small subunit & $1.6 \pm 0.2$ & $2.9 \pm 0.4$ \\
AK068920 & a-1,4-glucan branching enzyme & $1.4 \pm 0.2$ & $2.1 \pm 0.2$ \\
AK065121 & a-1,4-glucan branching enzyme & $3.7 \pm 0.3$ & $1.8 \pm 0.0$ \\
AK064893 & Phosphoglucomtase & $1.5 \pm 0.1$ & $1.9 \pm 0.1$ \\
AK099406 & Sucrose synthase & $1.5 \pm 0.1$ & $2.2 \pm 0.2$ \\
AK063766 & a-1,4-glucan phosphorylase & $2.2 \pm 0.1$ & $1.8 \pm 0.2$ \\
AK103367 & a-1,4-glucan phosphorylase & $1.4 \pm 0.1$ & $2.7 \pm 0.2$ \\
AK073216 & Sorbitol transporter & $1.7 \pm 0.3$ & $1.8 \pm 0.3$ \\
AK073967 & Hexose transporter & $1.4 \pm 0.1$ & $2.7 \pm 0.2$ \\
AK073216 & Sugar transporter & $1.3 \pm 0.2$ & $2.1 \pm 0.2$ \\
AK060577 & Glucose-6-phosphate translocator & $0.8 \pm 0.1$ & $2.0 \pm 0.4$ \\
AK059423 & Sugar transporter & $1.1 \pm 0.1$ & $2.2 \pm 0.1$ \\
AK069202 & Glucose transporter & $2.4 \pm 0.5$ & $2.0 \pm 0.1$ \\
AK103915 & Sugar transporter protein & & \\
\hline
\end{tabular}

In Zn-deficient roots, several starch granules were detected in the cortex, especially in the cells close to the sclerenchyma and endodermis (Figure 1d, f, g), and additional granules were observed in the pericycle (Figure 1e). In shoots, starch granules were mainly found in the mesophyll cells of the control plants (Figure 1h); however, in Zn-deficient shoots, the location of the starch granules was different among the leaves within a plant. Starch accumulated in the mesophyll cells of the youngest mature leaves of Zn-deficient rice (Figure 1i). When the youngest leaf was immature, starch accumulated in the bundle sheath cells of older leaves (Figure 1j). At the large vein of old leaves, starch granules were observed both in the mesophyll cells and in the bundle sheath cells (Figure 1k).

\section{$\mathrm{Zn}$-deficient rice strongly expresses inactive RNase}

Among the 27,800 genes analyzed, Os09g0537700 (AK061438; OsRNS4), which is predicted to encode S-like RNase, showed the highest induction ratio in roots (Table 3). This gene was also up-regulated in $\mathrm{Zn}$-deficient shoots. Other genes encoded putative RNases, were not significantly up-regulated by $\mathrm{Zn}$ deficiency. In rice eight genes for S-like RNase have been described (MacIntosh et al. 2010) and among them only six were included in our microarray experiment. In addition, the transcript levels of AK061438 in Zn-deficient shoots were much higher than those of the other RNases. Northern blot analysis revealed that the expression of two S-like RNases increased in Zndeficient shoots, but not in $\mathrm{Fe}$-deficient or $\mathrm{Cu}$-deficient shoots (Figure 2); Mn deficiency slightly induced expression. Although the expression ratio of AK061438 in Zndeficient roots was very high, the transcript level in roots was much lower than in shoots. Northern blot analysis as well as $22 \mathrm{~K}$ microarray analysis of rice plants indicated that expression of OsRNS5 also increases by Zn deficiency (Figure 2 \& Additional file 1: Table S2).

An alignment of the amino acid sequences of the RNases is shown in Figure 3a. All of the RNases contain eight conserved cysteine residues involved in the three-dimensional formation of RNase (Rabijns et al. 2002); however, the amino acid sequences encoded by AK061438 and AK109411 lack two histidine residues (replaced by Lys66 and Tyr125 in AK061438, and by Ala67 and Ser125 in AK109411) that are essential for RNA degradation (Kurihara et al. 1996). In addition, the glutamate residue, which is also essential for RNA degradation, is not conserved in AK109411 (replaced by Ala121). These histidine and glutamate residues are conserved in RNases in other plant species (Figure 3b), excluding CalsepRRP, which is an inactive RNase because it lacks one histidine residue (replaced by Lys70) essential for RNA degradation (Van Damme et al. 2000). Therefore, the proteins encoded by AK061438 and AK109411 may be inactive for RNA degradation (MacIntosh et al. 2010).

In contrast, RNA degradation increased in the crude extract of Zn-deficient citrullus (Sharma et al. 1981) and black gram (Pandey et al. 2002). RNA degradation in a crude extract of $\mathrm{Zn}$-deficient rice shoots was also higher than that in control shoots (Figure 4a), and it was inhibited by adding $\mathrm{ZnSO}_{4}$ but not $\mathrm{FeSO}_{4}$ (Figure $4 \mathrm{~b}$ ). These findings agree with a previous report showing that $\mathrm{Zn}$ ions inhibited RNA degradation in a crude extract of avena leaves (Wyen et al. 1971).

\section{Discussion}

The expression of genes involved directly or indirectly in $\mathrm{Zn}$ transport increases under Zn deficiency. Moreover, the genes involved in starch synthesis and transport were up-regulated by $\mathrm{Zn}$ deficiency. Both $\mathrm{Zn}$-deficient roots and shoots accumulated starch (Figure 1), in line with the gene expression pattern (Table 2). Starch may be used as a carbon source; therefore, it is assumed that Zn-deficient plants synthesize starch to withstand temporary abiotic stress. However, it is also possible that disruption of glycolysis by $\mathrm{Zn}$ deficiency causes an overaccumulation of soluble sugar, which ultimately results in starch accumulation. It is already reported that the activity of FBP aldolase in the glycolysis pathway decreased under Zn-deficiency in the leaves of oat and clover, and suggested that one of the reasons for a growth defect in plants grown under $\mathrm{Zn}$-deficient conditions is the breakdown of normal carbohydrate metabolism (QuinlanWatson 1951). The concentration of soluble sugar and 

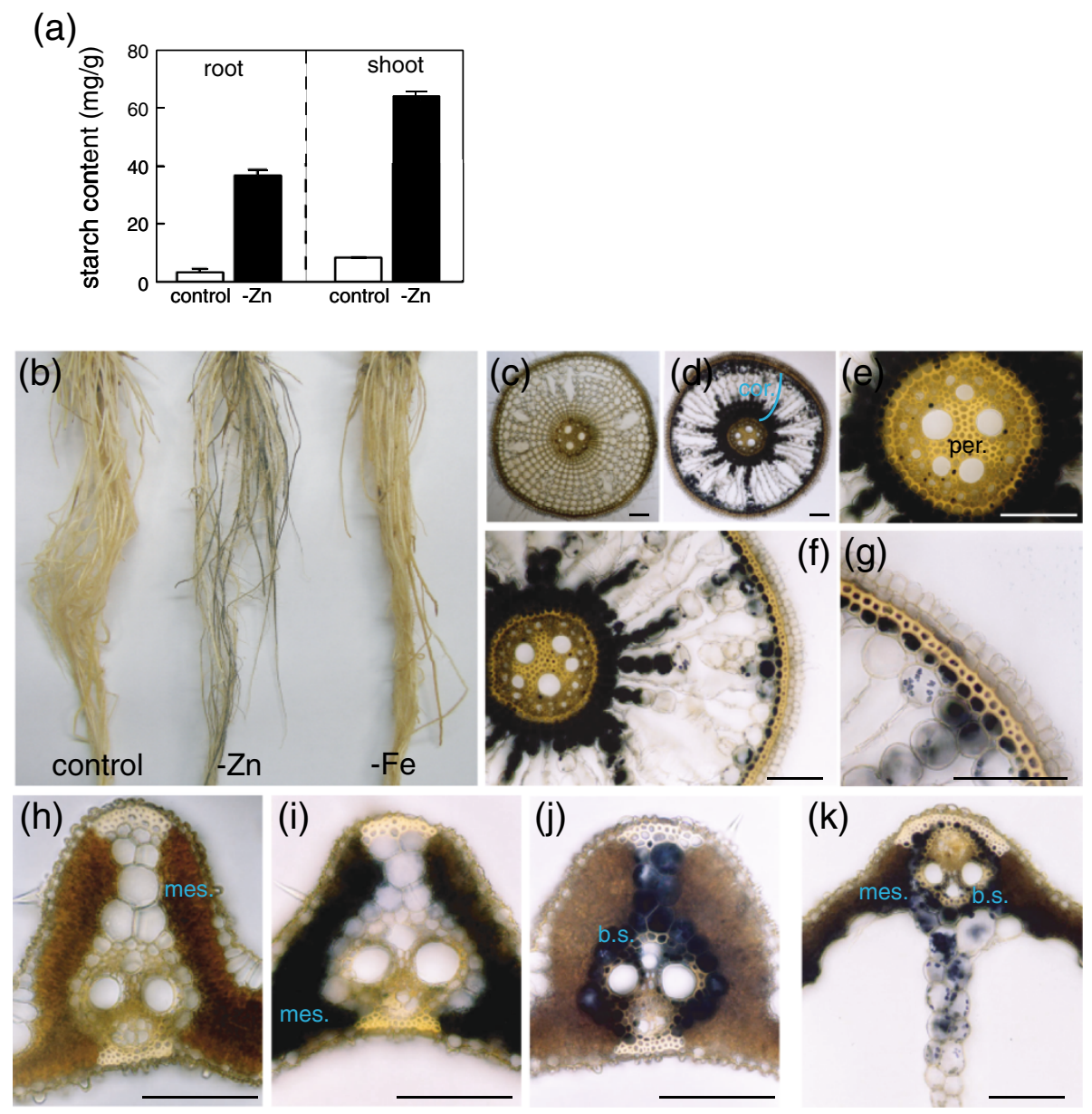

(f) $(\mathrm{g})$
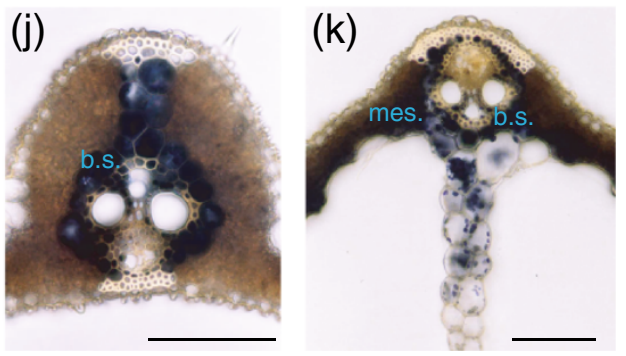

Figure 1 Quantification of starch (a) and localization of starch granules in Zn-deficient and Zn-sufficient (control) plants by iodine staining (b-k). (b) Zn- and Fe-sufficient roots (control); Zn-deficient roots (-Zn) and Fe-deficient roots (-Fe), (c) control roots, (d-g) Zn-deficient roots, (h) medium vein of old control leaf, (i) medium vein of Zn-deficient newest mature leaf, (j) medium vein of $Z n$-deficient old leaf, (k) large vein of Zn-deficient old leaf. Bar = $100 \mu \mathrm{m}$. cor.; cortex, mes.; mesophyll cells, b.s.; bundle sheath cells.

starch increase in Zn-deficient bean shoots (Marschner \& Cakmak 1989). An increase in soluble sugar would cause osmotic stress. We speculate that the starch might be synthesized to avoid osmotic stress due to increased soluble sugar in cells under $\mathrm{Zn}$ deficiency. Up-regulation of the genes that encode soluble sugar transporters due to Zn-deficiency suggests that sugar transporters help distribute sugar to avoid osmotic stress (Table 2).

Zn-deficient plants have increased RNase activity (Sharma et al. 1981; Pandey et al. 2002). We showed that Zn-deficient rice shoots also have increased RNA degradation (Figure 4a). Our microarray analysis revealed that the expression of one S-like RNase increased under Zn deficiency, and the transcript levels were much higher than those of other RNases (Table 3). However, unexpectedly, this RNase protein seemed to have no enzymatic activity as the histidine and glutamate residues essential for RNA degradation were changed (Figure 3a, b; (MacIntosh et al. 2010; Kurihara et al. 1996; Van Damme et al. 2000)). Our microarray analysis also showed that no gene for active RNases were up-regulated by $\mathrm{Zn}$ deficiency. In addition, $\mathrm{Zn}$ ions inhibited the RNase activity in a crude extract from $\mathrm{Zn}$-deficient shoots (Figure 4b). These findings suggest that RNA degradation may be controlled by the $\mathrm{Zn}$ concentration at a cellular level rather than by the level of RNase mRNA.

The function of the inactive RNase induced by $\mathrm{Zn}$ deficiency is not clear. An inactive S-like RNase accumulate in the rhizomes of Calystegia sepium and is suggested to play a role in vegetative storage proteins (Van Damme et al. 2000). Thus, $\mathrm{Zn}$-deficient rice might accumulate inactive RNase for storage of amino acids. The inactive RNase, also, accumulate in response to drought stress (Salekdeh et al. 2002), one of the most 
Table 3 Microarray profile of genes encoding RNase in rice

\begin{tabular}{llllc}
\hline $\begin{array}{l}\text { Accession } \\
\text { No. }\end{array}$ & Gene & \multicolumn{2}{l}{ Ratio $(-\mathbf{Z n} /+\mathbf{Z n})$} & $\begin{array}{c}\text { Putative } \\
\text { enzyme activity }\end{array}$ \\
\cline { 3 - 4 } & & Roots & Shoots & \\
\hline AK060320 & OsRNS1 & $0.6 \pm 0.1$ & $1.1 \pm 0.3$ & Yes \\
AK105061 & OsRNS2 & $1.1 \pm 0.1$ & $1.4 \pm 0.1$ & Yes \\
AK058502 & OsRNS3 & $1.2 \pm 0.3$ & $1.2 \pm 0.3$ & Yes \\
AK061438 & OsRNS4 & $29.2 \pm 10.7$ & $5.7 \pm 0.41$ & No \\
AK109411 & OsRNS5 & $1.0 \pm 0.0$ & $1.2 \pm 0.1$ & No \\
AK060320 & OsRNS6 & $0.6 \pm 0.1$ & $1.1 \pm 0.3$ & Yes \\
\hline
\end{tabular}

fatal stresses for plants. Therefore, the induction of the inactive RNase could be due to fatal stress for plants caused subsequently by Zn-deficiency stress. However, in our experiment, Fe-deficient stress decreased the expression of AK061438 and AK109411 (Figure 4), although Fe-deficient stress is more detrimental to plant growth than other micronutrient-deficient stresses. Moreover, the expression of AK061438 decreased under sulfur-deficient stress (Ohkama-Ohtsu et al. 2004). These data suggest that the induction of putative inactive RNases is specifically caused by Zn-or water-deficient stress rather than by general stress conditions in plants.

Taken together, $\mathrm{Zn}$-deficient rice plants accumulate starch that can be used as carbon and nitrogen sources. This might be involved in the tolerance to $\mathrm{Zn}$ deficiency, damage by $\mathrm{Zn}$-deficient stress, or $\mathrm{Zn}$ homeostasis. To better understand these mechanisms, it is important to elucidate the differences between $\mathrm{Zn}$-efficient and $\mathrm{Zn}$-inefficient cultivars, and the molecular functions of each gene involved in tolerance to $\mathrm{Zn}$ deficiency should be revealed.

\section{Conclusions}

Microarray analysis of $\mathrm{Zn}$ deficiency rice revealed the upregulation of several genes involved in starch synthesis in $\mathrm{Zn}$ deficient rice roots and shoots. The accumulation of

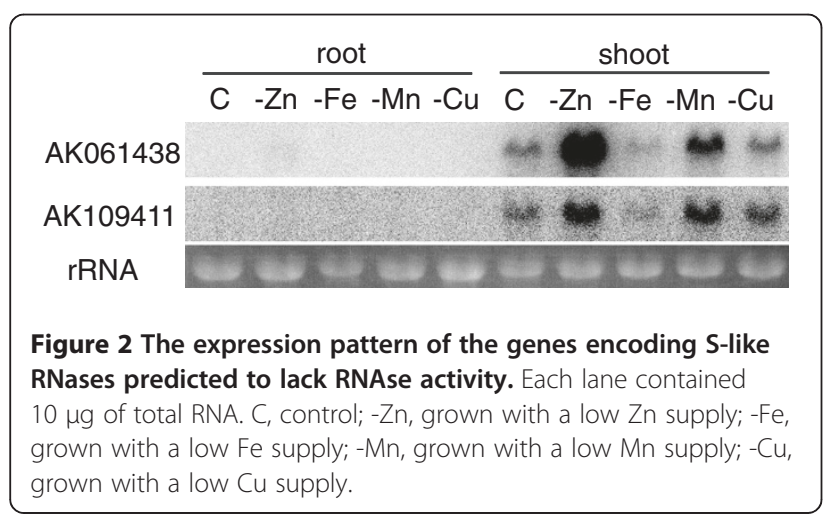

starch granules in the cortical cells of these tissues further supported these results. A gene encoding inactive RNase was much more highly transcribed than those encoding active RNases. Moreover, the level of RNA degradation in a crude extract of Zn-deficient shoots reduced after addition of $\mathrm{Zn}$ to a crude extract of $\mathrm{Zn}$-deficient shoots. These results suggest that the tolerance of rice plants to low levels of $\mathrm{Zn}$ may be promoted by the accumulation of starch and inactive RNase proteins.

\section{Methods}

\section{Plant materials and growth conditions}

Rice seeds (Oryza sativa L.) were germinated for 1 week at room temperature on paper towels soaked with distilled water. After germination, the seedlings were transferred to a Saran net floating on nutrient solution in a glasshouse for 2 weeks. Two week old plants were transferred to a $20-\mathrm{L}$ plastic container containing a nutrient solution as described previously (Suzuki et al. 2006) with or without $\mathrm{ZnSO}_{4}$, The $\mathrm{pH}$ of the nutrient solution was adjusted daily to 5.5 , and was renewed weekly. To compare the response of rice to $\mathrm{Zn}$ deficiency with that to deficiencies in other micronutrients, rice seeds were germinated for 1 week and then transferred to the nutrient solution described above. After 1 week, the seedlings were transferred to fresh nutrient solution without $\mathrm{Zn}$, $\mathrm{Fe}, \mathrm{Cu}$ or $\mathrm{Mn}$ and grown for 2 additional weeks.

\section{Microarray analysis}

Roots and shoots of four week old plants subjected to $\mathrm{Zn}$ deficiency or grown under control conditions were collected, frozen in liquid nitrogen, and stored at $-80^{\circ} \mathrm{C}$ until use. RNA was extracted from the roots and shoots of three plants, and total RNA (200 ng) from the Zn deficient and $\mathrm{Zn}$ sufficient plants were labelled with $\mathrm{Cy} 3$ or Cy5 using an Agilent Low RNA Input Fluorescent Linear Amplification Kit (Agilent Technologies), and rice $44 \mathrm{~K}$ oligo-DNA microarray analysis was performed in duplicate using color swaps, according to the manufacturer's instructions, as described previously (Bashir et al. 2011; Ishimaru et al. 2007). The induction ratios shown in the tables were calculated as the relative increases in expression under $\mathrm{Zn}$ deficiency compared to the level of expression under control conditions.

\section{Quantification of starch and iodine staining}

Rice seeds were germinated for 1 week and transferred to nutrient solution containing Zn. After 2 weeks, the seedlings were transferred to a $\mathrm{Zn}$-deficient nutrient solution for 3 weeks and harvested for analysis. The samples were collected $2 \mathrm{~h}$ before sunset. To determine the level of starch, each plant was ground using a mortar and pestle with liquid nitrogen and dried overnight at $65^{\circ} \mathrm{C}$. Around $50 \mathrm{mg}$ of dried plant tissue was used for starch quantification, employing a 
(a)
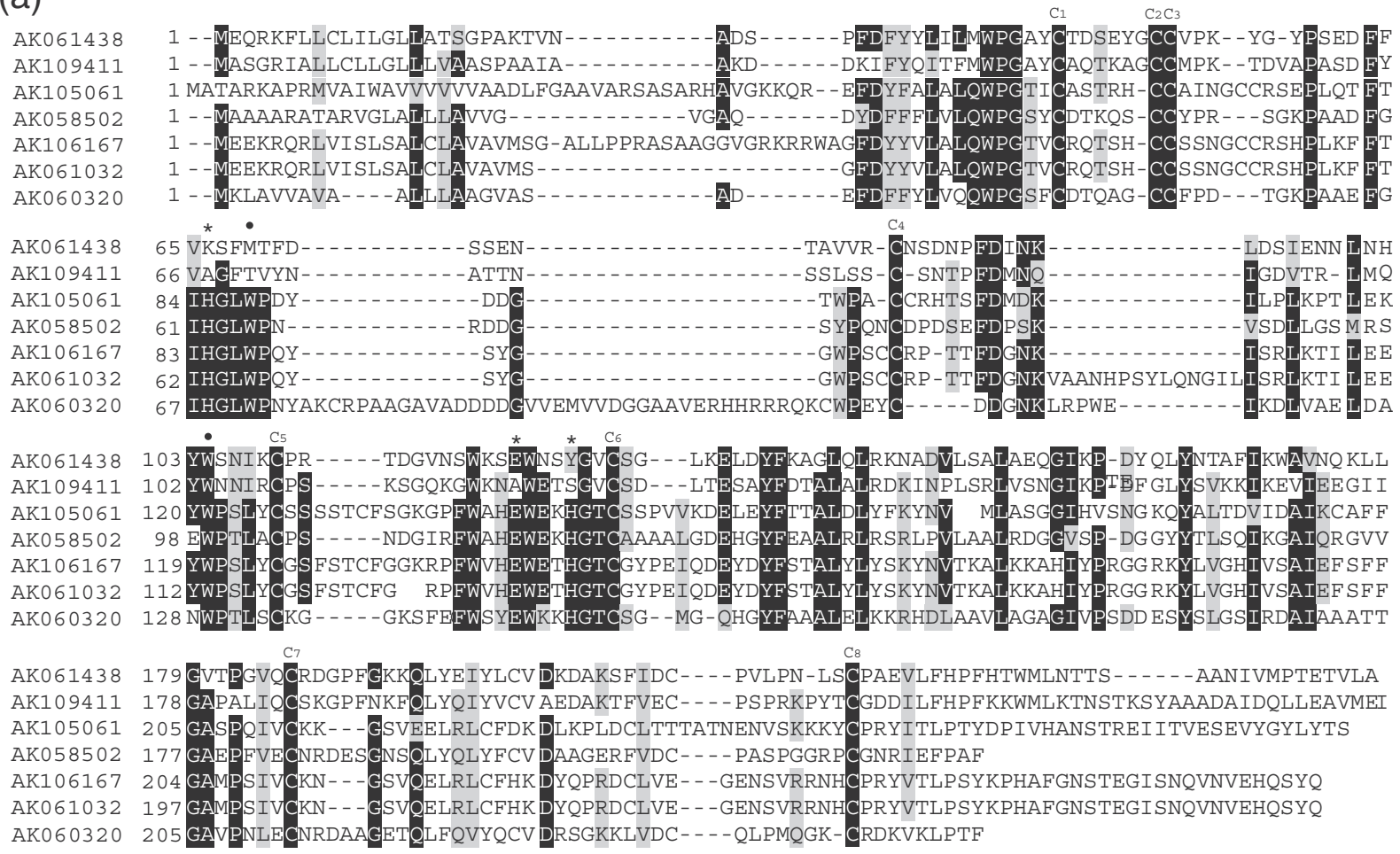

(b)
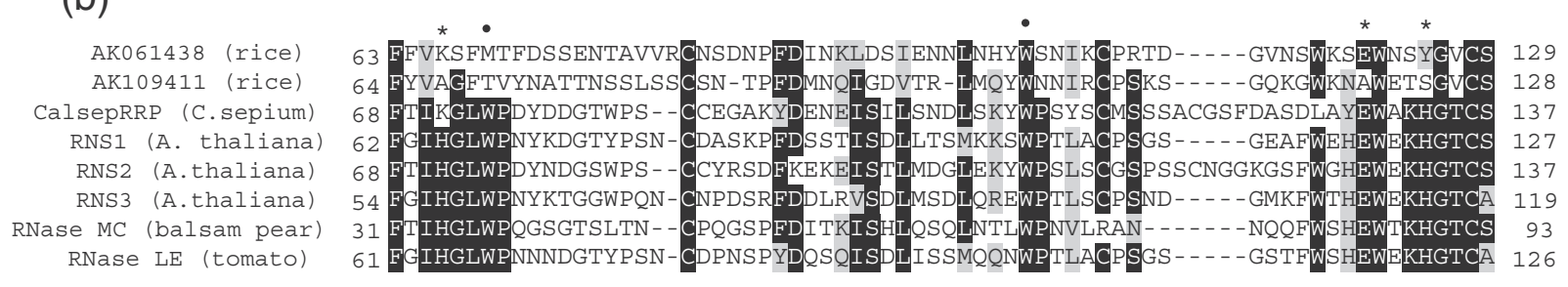

Figure 3 Comparison of the amino acid sequences of RNase and RNase-related proteins in plants. (a) All of the amino acid sequences predicted from the rice full-length cDNA database. (b) Partial amino acid sequences from C. sepium (CalsepRRP), A. thaliana (RNS1, RNS2, and RNS3), M. charantia (RNase MC), and L. esculentum (RNase LE). Gaps were introduced to maximize the homologies. Identical or similar residues are boxed in black and grey, respectively. The three charged residues involved in the active site of RNase are indicated by asterisks, and the two aromatic residues, which presumably maintain the conformational stability of the site, are indicated by a black circle. The sequences of the eight conserved cysteine residues in rice are indicated by C1-C8.

total starch assay procedure kit (Megazyme, Bray, Ireland). To determine the localization of the starch granules, leaf blades and roots were cut with a scalpel into approximately $1-\mathrm{cm}$ sections. These sections were embedded in 5\% agar and then cut into 80- to $130-\mu \mathrm{m}$ sections using a DTK-100 microslicer (Dosaka EM Co. Ltd., Kyoto, Japan) and stained with iodine. To remove the pigment in the leaf, the plant sections were soaked in $80 \%$ ethanol for 1 month.

\section{Measuring RNA degradation}

RNA degradation was detected by electrophoresis (Van Damme et al. 2000). Total RNA from rice shoots grown under $\mathrm{Zn}$-deficient treatment for 3 weeks was used as a substrate. A 10- $\mu$ g sample of total RNA was incubated in $20 \mu \mathrm{L}$ of $25 \mathrm{M}$ Tris- $\mathrm{HCl}$ (pH 7.4) containing $25 \mathrm{mM} \mathrm{KCl}$ and $5 \mathrm{mM} \mathrm{MgCl}$ in the presence of crude extracts from $\mathrm{Zn}$-deficient and control shoots at $30^{\circ} \mathrm{C}$ for $15 \mathrm{~min}$. To investigate the effects of metal on RNA degradation, $10 \mu \mathrm{g}$ of RNA were incubated with $1 \mathrm{mM}$ and $10 \mathrm{mM} \mathrm{ZnSO}_{4}$ and $\mathrm{FeSO}_{4}$ under the conditions described above. A 3- $\mu \mathrm{g}$ aliquot of incubated RNA diluted with distilled water was loaded onto a $1.2 \%$ agarose gel containing ethidium bromide. The extracts were prepared from $0.1 \mathrm{~g}$ of ground tissue mixed with $1 \mathrm{~mL}$ of Tris buffer. The amount of protein in the crude extract was quantified by the Bradford method. 


\section{Additional file}

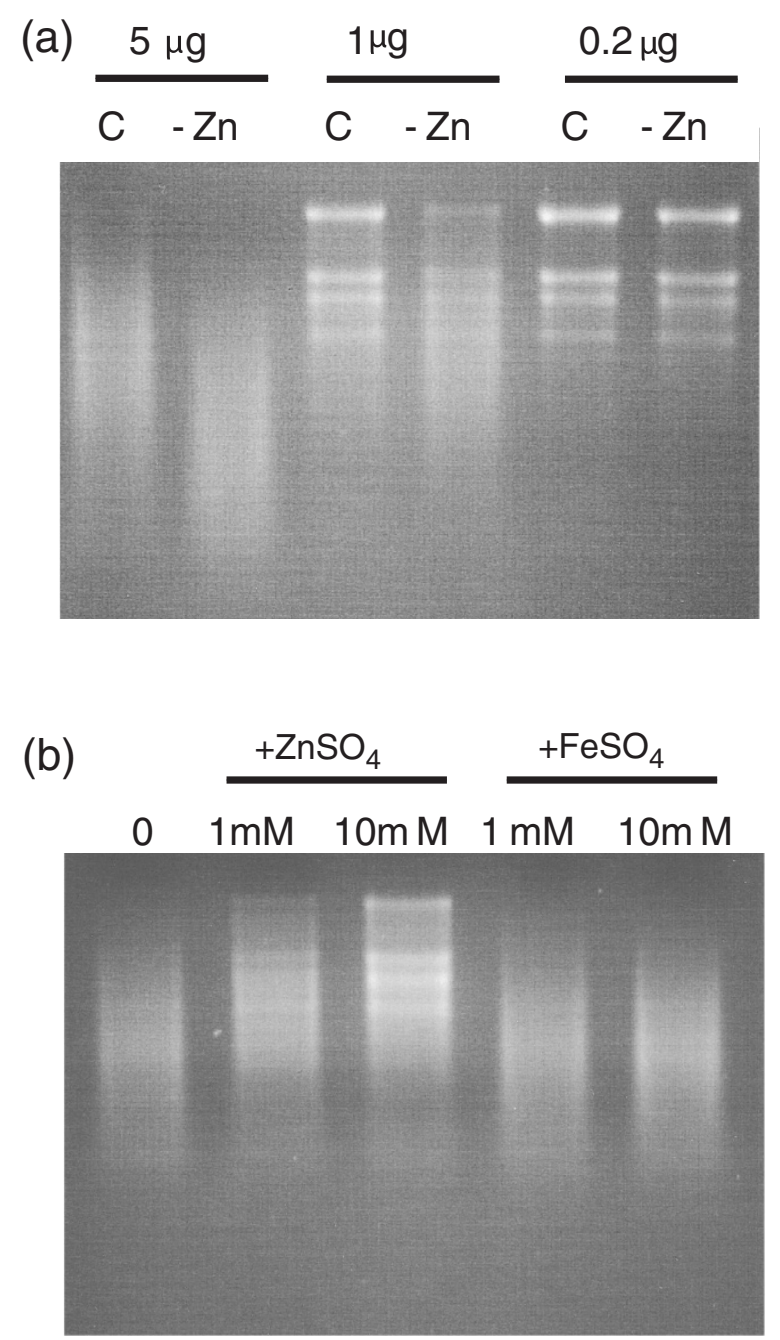

Figure 4 RNAse activity in crude extracts of rice shoots. (a)

$10 \mu \mathrm{g}$ of total RNA from Zn-deficient rice shoots were incubated with $5 \mu \mathrm{g}, 1 \mu \mathrm{g}$, and $0.2 \mu \mathrm{g}$ of protein from crude extracts of $\mathrm{Zn}$ deficient shoots $(-Z n)$ and control shoots (C). $3 \mu \mathrm{g}$ of incubated total RNA were loaded into each lane. (b) $10 \mu \mathrm{g}$ of total RNA from $\mathrm{Zn}$-deficient rice shoots and $2 \mu \mathrm{g}$ of protein from crude extracts of $\mathrm{Zn}$-deficient shoots were incubated together with $1 \mathrm{mM}$ or $10 \mathrm{mM}$ $\mathrm{ZnSO}_{4}$ or $\mathrm{FeSO}_{4} .3 \mu \mathrm{g}$ of incubated total RNA were loaded into each lane.

\section{Northern blot analysis}

Total RNA was extracted from roots and shoots, and $10 \mu \mathrm{g}$ per lane were electrophoresed in $1.2 \%(\mathrm{w} / \mathrm{v})$ agarose gels containing $0.66 \mathrm{M}$ formaldehyde, transferred to Hybond- $\mathrm{N}^{+}$membrane (Amersham Biosciences UK Ltd., Buckinghamshire, UK), and hybridized with probes at $65^{\circ} \mathrm{C}$. Northern blots were analyzed using BAS 3000 (FujiFilm, Tokyo, Japan). The full-length rice cDNAs (Rice Genome Resource Center, Tsukuba, Japan) were used for labelling the probes.
Additional file 1: Table-S1. Microarray analysis of genes involved in carbohydrate metabolism and transport in rice. The values present the average $\pm S E(n=4)$. Two weeks old rice plants were subjected to $Z n$ deficiency for two more weeks. Table S2. Microarray profile of genes encoding RNase in rice. The values present the average \pm SE $(n=4)$. Two weeks old rice plants were subjected to Zn deficiency for two more weeks.

\section{Abbreviations}

AGPase: ADP-glucose pyrophosphorylase; FBP aldolase: Fructose-1, 6-bisphosphate aldolase.

\section{Competing interests}

The authors declare no competing financial interests.

\section{Acknowledgments}

We thank Dr. Yoshiaki Nagamura (National Institute of Agrobiological Sciences, Tsukuba, Japan) for the microarray analysis and for providing full-length CDNA clones. We also thank Dr. Hitoshi Obata (Mie University, Tsu, Japan) for helpful advice and Dr. Takanori Kobayashi (The University of Tokyo, Tokyo, Japan) for careful reading of the manuscript. This work was supported by a grant from the Ministry of Agriculture, Forestry, and Fisheries of Japan (Green Technology Project IP-5003).

\section{Authors' contributions}

MS, MK, HN, and NN designed the research, MS performed the research and $M S, K B, H I, H N$, and NN discussed the data and wrote the paper. All authors read and approved the final manuscript.

\section{Authors' information}

M.S.; Present address; Aichi Steel Corporation, 1, Wanowari, Arao-Machi, Tokai-Shi, Aichi 476-8666, Japan H.I.; Present address: Division of Plant Sciences, National Institute of Agrobiological Sciences, 2-1-2 Kannondai, Tsukuba, Ibaraki 305-8602, Japan. M.T.; Present address: Faculty of Agriculture, Utsunomiya University - 350 Mine, Utsunomioya, Tochigi 321-8505, Japan.

Received: 13 February 2012 Accepted: 6 April 2012

Published: 6 April 2012

\section{References}

Baroja-Fernández E, Muñoz FJ, Zandueta-Criado A, Morán-Zorzano MT, Viale AM, Alonso-Casajús N, Pozueta-Romero J (2004) Most of ADP.glucose linked to starch biosynthesis occurs outside the chloroplast in source leaves. Proc Natl Acad Sci USA 101(35):13080-13085

Bashir K, Nishizawa NK (2006) Deoxymugineic acid synthase: A gene important for Fe-acquisition and homeostasis. Plant Signal Behav 1(6):292

Bashir K, Inoue H, Nagasaka S, Takahashi M, Nakanishi H, Mori S, Nishizawa N (2006) Cloning and characterization of deoxymugineic acid synthase genes from graminaceous plants. J Biol Chem 281(43):32395-32402

Bashir K, Ishimaru Y, Nishizawa NK (2010) Iron uptake and loading into rice grains. Rice 3(2):122-130

Bashir K, Ishimaru Y, Shimo H, Nagasaka S, Fujimoto M, Takanashi H, Tsutsumi N, An G, Nakanishi H, Nishizawa NK (2011) The rice mitochondrial iron transporter is essential for plant growth. Nat Commun 2:322. doi:10.1038/ ncomms 1326

Broadley MR, White PJ, Hammond JP, Zelko I, Lux A (2007) Zinc in plants. New Phytol 173(4):677-702

Cakmak I, Gülüt KY, Marschner H, Graham RD (1994) Efect of zinc and iron deficiency on phytosiderophore release in wheat genotypes differing in zinc efficiency. J Plant Nutr 17(1):1-17

Cakmak I, Sari N, Marschner H, Ekiz H, Kalayci M, Yilmaz A, Braun HJ (1996) Phytosiderophore release in bread and durum wheat genotypes differing in zinc efficiency. Plant Soil 180(2):183-189

Cakmak I, Ekiz H, Yilmaz A, Torun B, Köleli N, Gültekin I, Alkan A, Eker S (1997) Differential response of rye, triticale, bread and durum wheats to zinc deficiency in calcareous soils. Plant Soil 188(1):1-10 
Gao X, Zou C, Zhang F, van der Zee S, Hoffland E (2005) Tolerance to zinc deficiency in rice correlates with zinc uptake and translocation. Plant Soil 278 (1):253-261

Hacisalihoglu G, Hart JJ, Wang Y-H, Cakmak I, Kochian LV (2003) Zinc efficiency is correlated with enhanced expression and activity of zinc-requiring enzymes in wheat. Plant Physiol 131(2):595-602

Hajiboland R, Yang XE, Römheld V, Neumann G (2005) Effect of bicarbonate on elongation and distribution of organic acids in root and root zone of $\mathrm{Zn}$ efficient and Zn-inefficient rice (Oryza sativa L.) genotypes. Environ Exp Bot 54(2):163-173

Hoffland E, Wei C, Wissuwa M (2006) Organic anion exudation by lowland rice (Oryza sativa L.) at zinc and phosphorus deficiency. Plant Soil 283(1):155-162

Inoue H, Higuchi K, Takahashi M, Nakanishi H, Mori S, Nishizawa NK (2003) Three rice nicotianamine synthase genes, OsNAS1, OsNAS2, and OsNAS3 are expressed in cells involved in long-distance transport of iron and differentially regulated by iron. Plant J 36(3):366-381

Ishimaru Y, Suzuki M, Kobayashi T, Takahashi M, Nakanishi H, Mori S, Nishizawa NK (2005) OsZIP4, a novel zinc-regulated zinc transporter in rice. J Exp Bot 56 (422):3207-3214

Ishimaru Y, Masuda H, Suzuki M, Bashir K, Takahashi M, Nakanishi H, Mori S, Nishizawa NK (2007) Overexpression of the OsZIP4 zinc transporter confers disarrangement of zinc distribution in rice plants. J Exp Bot 58(11):2909-2915

Ishimaru Y, Bashir K, Fujimoto M, An G, Itai R, Tsutsumi N, Nakanishi H, Nishizawa NK (2009) Rice-specific mitochondrial iron-regulated gene (MIR) plays an important role in iron homeostasis. Mol Plant 2(5):1059-1066

Ishimaru Y, Bashir K, Nishizawa NK (2011) Zn uptake and translocation in rice plants. Rice 4(1):21-27

Kitagishi K, Obata H (1986) Effects of zinc on the nitrogen metabolism of meristematic tissues of rice plants with reference to protein synthesis. Soil Sci Plant Nutr 32(3):397-405

Kurihara H, Nonaka T, Mitsui Y, Ohgi K, Irie M, Nakamura KT (1996) The crystal structure of ribonuclease $\mathrm{Rh}$ from Rhizopus niveus at $2.0 \AA$ resolution. J Mol Biol 255(2):310-320

Lee S, Jeong H, Kim S, Lee J, Guerinot M, An G (2010) OsZIP5 is a plasma membrane zinc transporter in rice. Plant Mol Biol 73(4):507-517

Ma JF, Shinada T, Matsuda C, Nomoto K (1995) Biosynthesis of phytosiderophores, mugineic acids, associated with methionine cycling. J Biol Chem 270(28):16549-16554

Ma JF, Taketa S, Chang Y-C, Iwashita T, Matsumoto H, Takeda K, Nomoto K (1999) Genes controlling hydroxylations of phytosiderophores are located on different chromosomes in barley (Hordeum vulgare L.). Planta 207(4):590-596

MacIntosh G, Hillwig M, Meyer A, Flagel L (2010) RNase T2 genes from rice and the evolution of secretory ribonucleases in plants. Mol Genet Genomics 283(4):381-396

HMarschner1995Mineral nutrition of higher

plants2AcademicLondon347364Marschner H (1995) Mineral nutrition of higher plants, 2nd edn. Academic, London, pp 347-364

Marschner H, Cakmak I (1989) High light intensity enhances chlorosis and necrosis in leaves of zinc, potassium, and magnesium deficient bean (Phaseolus vulgaris) plants. J Plant Physiol 134:308-315

Mori S, Nishizawa NK (1987) Methionine as a dominant precursor of phytosiderophores in graminaceae plants. Plant Cell Physiol 28(6):1081-1092

Nishiyama R, Kato M, Nagata S, Yanagisawa S, Yoneyama T (2012) Identification of Zn-nicotianamine and Fe-2'-deoxymugineic acid in the phloem saps from rice plants (Oryza sativa L.). Plant and Cell Physiology 53:381-390

Ohkama-Ohtsu N, Klshimoto N, Yazaki J, Fujii F, Shinbo K, Shimatani Z, Nagata Y, Hashimoto A, Ohta T, Sato Y et al (2004) Up-regulation of genes for ferritin, RNase, and DnaJ in leaves of rice plants in response to sulfur deficiency. Soil Sci Plant Nutr 50:771-775

Pandey N, Pathak GC, Singh AK, Sharma CP (2002) Enzymic changes in response to zinc nutrition. J Plant Physiol 159(10):1151-1153

Pearson JN, Rengel Z (1997) Genotypic differences in the production and partitioning of carbohydrates between roots and shoots of wheat grown under zinc or manganese deficiency. Ann Bot 80(6):803-808

Ptashnyk M, Roose T, Jones DL, Kirk GJD (2011) Enhanced zinc uptake by rice through phytosiderophore secretion: a modelling study. Plant Cell Environ 34 (12):2038-2046

Quinlan-Watson TAF (1951) Aldolase activity in zinc-deficient plants. Nature 167 (4260):1033-1034
Rabijns A, Verboven C, Rouge P, Barre A, Van Damme EJM, Peumans WJ, De Ranter CJ (2002) Structure of an RNase-related protein from Calystegia sepium. Acta Crystallogr Sect D 58(4):627-633

Rengel Z, Graham RD (1996) Uptake of zinc from chelate-buffered nutrient solutions by wheat genotypes differing in zinc efficiency. J Exp Bot 47(2):217-226

Riechmann JL, Heard J, Martin G, Reuber L, Jiang CZ, Keddie J, Adam L, Pineda O, Ratcliffe OJ, Samaha RR et al (2000) Arabidopsis transcription factors: genome-wide comparative analysis among eukaryotes. Science 290 (5499):2105-2110

Salekdeh GH, Siopongco J, Wade LJ, Ghareyazie B, Bennett J (2002) Proteomic analysis of rice leaves during drought stress and recovery. Proteomics 2(9):1131-1145

Sharma CP, Gupta JP, Agarwala SC (1981) Metabolic changes in citrullus subjected to zinc stress. J Plant Nutr 3(1-4):337-344

Shojima S, Nishizawa N-K, Fushiya S, Nozoe S, Irifune T, Mori S (1990) Biosynthesis of phytosiderophores: In vitro biosynthesis of 2'-deoxymugineic acid from L-methionine and nicotianamine. Plant Physiol 93(4):1497-1503

Smith AM, Zeeman SC, Thorneycroft D, Smith SM (2003) Starch mobilization in leaves. J Exp Bot 54(382):577-583

Suzuki M, Takahashi M, Tsukamoto T, Watanabe S, Matsuhashi S, Yazaki J, Kishimoto N, Kikuchi S, Nakanishi H, Mori S et al (2006) Biosynthesis and secretion of mugineic acid family phytosiderophores in zinc-deficient barley. Plant J 48 (1):85-97

Suzuki M, Tsukamoto T, Inoue H, Watanabe S, Matsuhashi S, Takahashi M, Nakanishi H, Mori S, Nishizawa NK (2008) Deoxymugineic acid increases Zn translocation in Zn-deficient rice plants. Plant Mol Biol 66(6):609-617

Van Damme EJM, Hao Q, Barre A, Rougé P, Van Leuven F, Peumans WJ (2000) Major protein of resting rhizomes of Calystegia sepium (Hedge Bindweed) closely resembles plant RNases but has no enzymatic activity. Plant Physiol 122(2):433-446

Walter A, Römheld V, Marschner H, Mori S (1994) Is the release of phytosiderophores in zinc-deficient wheat plants a response to impaired iron utilization? Physiol Plant 92(3):493-500

Widodo B, Broadley MR, Rose T, Frei M, Pariasca-Tanaka J, Yoshihashi T, Thomson M, Hammond JP, Aprile A, Close TJ et al (2010) Response to zinc deficiency of two rice lines with contrasting tolerance is determined by root growth maintenance and organic acid exudation rates, and not by zinc-transporter activity. New Phytol 186(2):400-414

Williams LE, Mills RF (2005) P1B-ATPases - an ancient family of transition metal pumps with diverse functions in plants. Trends Plant Sci 10(10):491-502

Wissuwa M, Ismail AM, Yanagihara S (2006) Effects of zinc deficiency on rice growth and genetic factors contributing to tolerance. Plant Physiol 142(2):731-741

Wyen NV, Erdei S, Farkas GL (1971) Isolation from avena leaf tissues of a nuclease with the same type of specificity towards RNA and DNA: Accumulation of the enzyme during leaf senescence. Biochim Biophys Acta 232:472-483

Yang X, Huang J, Jiang Y, Zhang H-S (2009) Cloning and functional identification of two members of the ZIP (Zrt, Irt-like protein) gene family in rice (Oryza sativa L.) Mol Biol Rep 36(2):281-287

Zhang F, Römheld V, Marschner H (1989) Effect of zinc deficiency in wheat on the release of zinc and iron mobilizing root exudates. $Z$ für Pflanzenernährung Bodenkunde 152(2):205-210

doi:10.1186/1939-8433-5-9

Cite this article as: Suzuki et al: Accumulation of starch in Zn-deficient rice. Rice 2012 5:9. 